\title{
COMPARATIVE DECALCIFICATION METHODS, RADIOCARBON DATES, AND STABLE ISOTOPES OF THE VIRI BONES
}

\author{
Noreen Tuross \\ Department of Human Evolutionary Biology, 11 Divinity Avenue, Harvard University, Cambridge, Massachusetts 02130, \\ USA.Email: tuross@fas.harvard.edu.
}

\begin{abstract}
The Fifth International Radiocarbon Comparison (VIRI) provided a suite of 5 bone samples with consensus ages ranging from 969 to $39,305{ }^{14} \mathrm{C}$ yr BP (Scott et al. 2010). These bones were used herein in a comparison of decalcification methods using either $\mathrm{HCl}$ or EDTA to produce collagen, and the results demonstrate age concordance between both preparation methods and the VIRI consensus values. Additional isotopic analyses of the collagen $\left(\delta^{13} \mathrm{C}, \delta^{15} \mathrm{~N}\right.$, and $\left.\delta^{18} \mathrm{O}\right)$ illustrate the increasing sensitivity of carbon, nitrogen, and oxygen isotopes in assessing gelatin degradation.
\end{abstract}

\section{INTRODUCTION}

As part of a multiphase interlaboratory comparison, the Fifth International Radiocarbon Comparison (VIRI) provided 5 bone samples of varying ages to participants. The method of collagen preparation was not prescribed in the VIRI comparison; thus, the VIRI results stand as a comparison of laboratory methods used in isolating collagen as well as post-isolation measurement of ${ }^{14} \mathrm{C}$ content in the samples. More than 60 sets of ${ }^{14} \mathrm{C}$ dates from 42 laboratories, as well as consensus values, were published by Scott et al. (2010).

Collagen (Type I), the matrix protein utilized in the ${ }^{14} \mathrm{C}$ dating of bones and dentin, is a largely insoluble polymer. The protein exists with varying amounts of crosslinking, and thus differs in its solubility profile, during the development of the skeleton (Jackson and Bentley 1960). In sample preparation for ${ }^{14} \mathrm{C}$ dating, the protein (collagen) is isolated from the calcium phosphate mineral by demineralization, typically using hydrochloric acid $(\mathrm{HCl})$. Gelatin is then derived from the isolated collagen using methods combining acid of low molarity and heat. While collagen (Type I) denotes a particular complex protein of known composition, gelatin is a more generic term used to describe a group of peptides and proteins generally derived from Type I collagen. The gelatinization process is destructive and involves both the disruption of hydrogen bonds involved in helix stabilization and selected peptide bond cleavage (Eastoe 1955; Veis and Anesey 1965; Piszkiewicz et al. 1970; Zhang et al. 2006).

The majority of laboratories that participated in the VIRI bone comparison utilized the Longin (1971) method for collagen isolation from the mineral phase, with occasional modifications (Scott et al. 2010). Longin (1971) described a protocol utilizing crushed bone $(0.2 \mathrm{~mm})$ that is pretreated in $8 \% \mathrm{HCl}$ for a short period of time to remove most of the mineral phase. The insoluble remainder is then heated in $\mathrm{pH} 3$ at $90{ }^{\circ} \mathrm{C}$ to produce soluble gelatin. No assessments of authenticity or purity of the resulting degraded protein were offered in this publication (Longin 1971), although numerous authors (e.g. Berglund et al. 1976; Gurfinkel 1987; Arslanov and Svezhentsev 1993) have developed and tested the approach. The general Longin-type protocol now includes a weakly basic $(\mathrm{NaOH})$ extraction after decalcification first suggested by Haynes (1967). In addition, ongoing modifications to the Longin protocol, such as ultrafiltration, are being employed by a number of ${ }^{14} \mathrm{C}$ laboratories (Brown et al. 1988; Higham et al. 2006).

The isolation of collagen from bone by acid dissolution of the mineral phase has served the ${ }^{14} \mathrm{C}$ community and their consumers well. However, the use of $\mathrm{HCl}$ is relatively harsh even at the lower concentrations found to be effective in 2 recent studies (Beaumont et al. 2010; Pestle 2010). The use of

(C) 2012 by the Arizona Board of Regents on behalf of the University of Arizona Proceedings of the 6th International Radiocarbon and Archaeology Symposium, edited by E Boaretto and N R Rebollo Franco RADIOCARBON, Vol 54, Nr 3-4, 2012, p 837-844 
$\mathrm{HCl}$ decalcification has been largely abandoned by investigators seeking to preserve histology or isolate DNA from mineralized tissues (Frank et al. 1993; Gilbert et al. 2005; Salamon et al. 2005).

Hedges and van Klinken (1992) have noted the importance of having both multiple approaches and multiple assessment strategies to deal with the range of preservation in the calcified tissue that arrives at ${ }^{14} \mathrm{C}$ laboratories. There are 2 major reasons for considering the use of gentle decalcifying agents, such as ethylenediaminetetraacetic acid (EDTA) in collagen preparation for ${ }^{14} \mathrm{C}$ dates. First, many bones recovered by archaeologists or paleontologists will not yield collagen with $\mathrm{HCl}$ decalcification. The degradation of the collagen molecule proceeds with bond breakage of several types, including the scission of peptide bonds to produce smaller fragments - an in situ gelatinization process (e.g. Eastoe 1955; Veis 1964; Bensusan and Nielsen 1964; Silva et al. 2005). Longin-like preparation methods assume that ancient bone collagen, like modern bone collagen, is insoluble in $\mathrm{HCl}$. This assumption can lead to an underestimation of protein preservation in archaeological or paleontological bone (and dentin). Second, the application of $\mathrm{HCl}$ to bone precipitates any associated humic acids in the sample into the insoluble phase where collagen is found. The use of the chelating agent (EDTA) not only removes the calcium phosphate mineral phase, but also solubilizes humic acids (e.g. Liu and Fang 2002).

The use of calcium chelators, specifically EDTA, in the preparation of collagen for ${ }^{14} \mathrm{C}$ dates has been reported previously (Olsson et al. 1974; El-Daoushy et al. 1978; Olsson 2000), and multiple analytical issues discussed. As with many tests of methods development, the question of the "correct" answer has been at issue, and the publication of the VIRI data (Scott et al. 2010) provides a robust comparator to assess decalcification methods. Additional isotopic and elemental data $\left(\delta^{13} \mathrm{C}\right.$, $\delta^{15} \mathrm{~N}$, and $\delta^{18} \mathrm{O}$ ) from the VIRI bone samples provide additional information on the condition of the extracted collagen.

\section{MATERIALS AND METHODS}

Five bones, designated $\mathrm{E}$ to I in the VIRI comparison, served as the basis of this study. The complete description of each of the samples can be found in Scott et al. (2010). Briefly, sample E is a mammoth bone from the Yukon territory more that 5 half-lives in age; sample $\mathrm{F}$ is a horse bone from Siberia less than 1 half-life in age; sample $\mathrm{G}$ is a human bone of known age from a dendrochronology dated coffin approximately $1000 \mathrm{yr}$ old; and samples $\mathrm{H}$ and I are both whale bones from Norway approximately 2 half-lives in age. The ${ }^{14} \mathrm{C}$ dates reported in this paper were produced as part of the VIRI intercomparison. These dates and the consensus dates derived from that study (Scott et al. 2010) are reported in Table 1 and Figure 1.

Isolation of insoluble collagen from less than $500 \mathrm{mg}$ of small bone chunks was performed by 2 methods. In the $\mathrm{HCl}$ method, the bone was subjected to gentle swirling in $1 \mathrm{~N} \mathrm{HCl}$ at room temperature for up to $10 \mathrm{hr}$. The insoluble pseudomorph of collagen was recovered and rinsed in ultrapure water. The collagen was then submerged in $0.1 \mathrm{~N} \mathrm{NaOH}$ for $30 \mathrm{~min}$, and finally rinsed in 5 ultrapure water washes. The collagen pseudomorph was then transferred to a Teflon ${ }^{\circledR}$-capped glass tube, which had been previously muffle-oven cleaned, and heated in a $\mathrm{pH} 3(\mathrm{HCl})$ solution, a common approach in the Longin-like protocols, at $100^{\circ} \mathrm{C}$ for $16 \mathrm{hr}$. The solution was then filtered through a coarse glass sintered funnel into another clean glass tube and freeze-dried.

For EDTA decalcification (after Tuross et al. 1988), small bone chunks were soaked and gently swirled in $50 \mathrm{~mL}$ of $0.5 \mathrm{M}$ EDTA at $\mathrm{pH} 7.4$ for periods up to several weeks, and the EDTA solution was changed every 4-5 days. The EDTA solution was made with tetrasodium salt and the solution titrated down to $\mathrm{pH} 7.4$ with $\mathrm{HCl}$. Decalcification was complete when the bone pieces became trans- 
lucent, and, generally, the collagen would float in solution. The pseudomorphs were washed 15 times in ultrapure water, and at least one of these washes was overnight. Both the completeness of the mineral removal and the removal of EDTA was monitored in the original report of this process (Tuross et al. 1988). EDTA was not detectable by the 7th water wash, so the protocol called for double this number of washes as an analytical safety measure. Small pieces of collagen were removed for natural abundance isotopic measurements, and the remaining pieces were gelatinized as described above with the exception that the gelatinizing solution was at $\mathrm{pH} 5$ in an attempt to stay as near to neutrality as possible during gelatinization.

These protocols were developed without regard to the extent of time for sample preparation. The use of whole bone (as opposed to powdered) is common in laboratories that perform light isotope ratio mass spectrometry, and offers the advantage that, after decalcification, any nonpseudomorph insoluble material will be discarded. All of the samples were analyzed for ${ }^{14} \mathrm{C}$ at the National Ocean Sciences Accelerator Mass Spectrometry (NOSAMS) facility at the Woods Hole Oceanographic Institute (WHOI), Massachusetts, USA.

The light stable isotopes of carbon $\left(\delta^{13} \mathrm{C}\right)$, nitrogen $\left(\delta^{15} \mathrm{~N}\right)$, and oxygen $\left(\delta^{18} \mathrm{O}\right)$ were analyzed in continuous-flow mode on a Finnigan Delta XL isotope ratio mass spectrometer. Isotopic compositions of ${ }^{13} \mathrm{C}$ and ${ }^{15} \mathrm{~N}$ are reported relative to VPDB and Air, respectively. Elemental compositions of carbon and nitrogen were determined using acetanilide as a standard $(\% \mathrm{C}=71.1, \% \mathrm{~N}=10.4$; acetanilide: $\delta^{15} \mathrm{~N}=0.5 \%, \delta^{13} \mathrm{C}=-30.9 \%$ ), and separation of the $\mathrm{CO}_{2}$ and $\mathrm{N}_{2}$ was done in a Costech elemental analyzer. Oxygen isotopic compositions were measured by high-temperature combustion in a Thermo High Temperature Conversion/Elemental Analyzer (TC/EA) (Sharp et al. 2001). The factory-installed gas chromatography $(\mathrm{GC})$ column in the TC/EA was replaced with a $1.8-\mathrm{m}$ packed $5 \AA$-molecular sieve column (Tuross et al. 2008). Oxygen isotope composition was reported relative to VSMOW and normalized using VSMOW and SLAP. IAEA-601 $\left(\delta^{18} \mathrm{O}=23.3 \%\right.$ ) and IAEA-602 $\left(\delta^{18} \mathrm{O}=71.4 \%\right.$ ) were used as standards and internal secondary standards of keratin and gelatin were included in each run (keratin: $\delta^{15} \mathrm{~N}=7.2 \%, \delta^{13} \mathrm{C}=-24 \%$; gelatin: $\delta^{15} \mathrm{~N}=7.2 \%$, $\delta^{13} \mathrm{C}=-14.5 \%$ ). The average $\delta^{18} \mathrm{O}$ of water used in the decalcification and gelatinization procedures was $-7.2 \%$.

\section{RESULTS}

Both decalcification methods produced ${ }^{14} \mathrm{C}$ dates (Table 1 and Figure 1 ) in agreement with the consensus dates in the VIRI intercomparison of 35 (sample G) to 59 (sample I) observations (Scott et al. 2010). All but 2 of the ${ }^{14} \mathrm{C}$ dates of EDTA- and $\mathrm{HCl}$-decalcified bone in this study from single (samples E, F, and G) or duplicate (samples H and I) analyses overlapped the $1 \sigma$ VIRI consensus values (Figure 1), and none of the ${ }^{14} \mathrm{C}$ dates from the individual samples reported here were rejected as outliers in the VIRI comparison. In sum, the ${ }^{14} \mathrm{C}$ dates obtained from EDTA decalcification of the VIRI bones were indistinguishable from both the in-house $\mathrm{HCl}$ processing and a comparative data set from a large number of laboratories (Scott et al. 2010).

The $\delta^{13} \mathrm{C}_{\mathrm{VPDB}}$ values of the EDTA and $\mathrm{HCl}$ individual gelatins from this laboratory agreed with the consensus values of VIRI within 1 standard deviation and between decalcification methods within each sample (Table 2$)$. Nitrogen isotopic values $\left(\delta^{15} \mathrm{~N}_{\mathrm{AIR}}\right)$ generally agreed between decalcification methods, although the amount of nitrogen in the $\mathrm{HCl}$-generated collagens is slightly lower than that of the EDTA-decalcified collagens, and noticeably so in sample I (Figure 2). The nitrogen isotopic composition of this sample (I) also differed between the $\mathrm{HCl}$ - and the EDTA-extracted collagens (Table 2). The absolute $\delta^{15} \mathrm{~N}_{\mathrm{AIR}}$ followed expected differences of relatively low values in terrestrial herbivores and much higher values in marine mammals. The elemental carbon to nitrogen ratios 
were nearly identical in all samples measured (Table 2). The overall carbon and nitrogen data supports an interpretation of well-preserved fossil bone.

Table 1 Comparison of results for samples prepared by the ETDA and $\mathrm{HCl}$ methods.

\begin{tabular}{llllcc}
\hline $\begin{array}{l}\text { VIRI } \\
\text { code }\end{array}$ & $\begin{array}{l}\text { Bone } \\
\text { material }\end{array}$ & $\begin{array}{l}\text { Preparation } \\
\text { method }\end{array}$ & $\begin{array}{l}\text { Accession } \\
\text { nr }\end{array}$ & $\begin{array}{l}\text { Age } \\
\text { yr BP }\end{array}$ & $\begin{array}{l}\text { Consensus } \\
\text { (Scott et al. 2010) }\end{array}$ \\
\hline E & Mammoth & EDTA & OS-55008 & $39,000 \pm 300$ & 39,305 \\
E & Mammoth & HCl & OS-55009 & $36,400 \pm 310$ & \\
F & Horse & EDTA & OS-55010 & $2540 \pm 30$ & 2513 \\
F & Horse & HCl & OS-55011 & $2550 \pm 35$ & \\
G & Human & EDTA & OS-55012 & $940 \pm 40$ & 969 \\
H & Whale & EDTA & OS-55013 & $9490 \pm 40$ & 9528 \\
H & Whale & HCl & OS-55014 & $9530 \pm 50$ & \\
H & Whale & EDTA & OS-55041 & $9470 \pm 45$ & \\
H & Whale & HCl & OS-55042 & $9590 \pm 50$ & \\
I & Whale & EDTA & OS-55015 & $8220 \pm 50$ & 8331 \\
I & Whale & HCl & OS-55016 & $8290 \pm 55$ & \\
I & Whale & EDTA & OS-55043 & $8360 \pm 40$ & \\
I & Whale & HCl & OS-55044 & $8390 \pm 40$ & \\
\hline
\end{tabular}
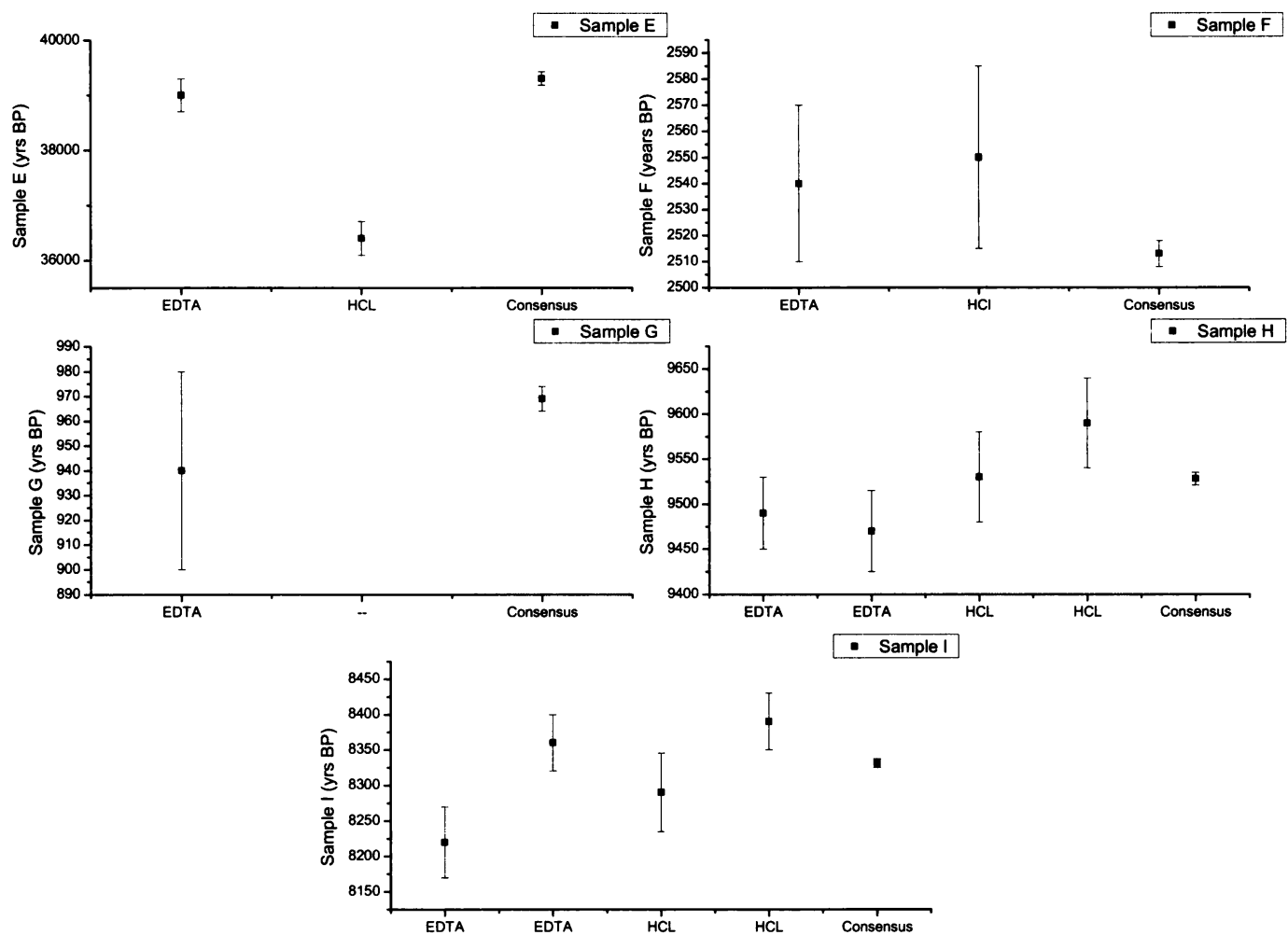

Figure 1 The age in yr BP of 5 samples from the VIRI comparison. Calculated ages and associated uncertainties are given for each extraction type, $\mathrm{HCl}$ or EDTA. There was insufficient material to extract sample $\mathrm{G}$ with $\mathrm{HCl}$. Also included on each graph is the calculated consensus $\pm 1 \sigma$ from multiple laboratories that participated in VIRI (Scott et al. 2010). The EDTA used in these experiments was beyond $45,000 \mathrm{yr}{ }^{14} \mathrm{C}$ age. 
Table 2 Results for EDTA and $\mathrm{HCl}$ methods compared with VIRI values.

\begin{tabular}{|c|c|c|c|c|c|c|}
\hline \multirow[b]{2}{*}{ Sample } & \multicolumn{3}{|c|}{$\delta^{13} \mathrm{C}_{\mathrm{VPDB}}$} & \multicolumn{2}{|c|}{$\delta^{15} \mathrm{~N}_{\mathrm{air}}$} & \multirow[b]{2}{*}{$\mathrm{C} / \mathrm{N}^{\mathrm{b}}$} \\
\hline & mean $\pm \mathrm{SD}_{\text {consensus }}{ }^{\mathrm{a}}$ & EDTA $_{\text {gelatin }}$ & $\mathrm{HCl}_{\text {gelatin }}$ & EDTA $_{\text {gelatin }}$ & $\mathrm{HCl}_{\text {gelatin }}$ & \\
\hline $\mathrm{E}$ & $-21.4 \pm 2.5$ & -21.0 & -21.0 & 7.0 & 7.1 & $2.9 / 2.9$ \\
\hline$F$ & $-20.5 \pm 2.0$ & -20.7 & -20.4 & 6.1 & 6.3 & $2.9 / 2.9$ \\
\hline G & $-20.4 \pm 2.0$ & -20.1 & NA & 11.0 & NA & $2.9 / 2.9$ \\
\hline $\mathrm{H}$ & $-16.3 \pm 1.7$ & -16.6 & -16.7 & 14.3 & 13.8 & $2.9 / 2.9$ \\
\hline I & $-16.3 \pm 4.8^{c}$ & -16.5 & -17.0 & 13.5 & 12.8 & $2.9 / 2.9$ \\
\hline
\end{tabular}

${ }^{\mathrm{a} F r o m ~ S c o t t ~ e t ~ a l . ~(2010) . ~}$

${ }^{\mathrm{b}} \mathrm{All} \mathrm{C} / \mathrm{N}$ values ranged from $2.88-2.93$ in duplicate samples. The $\delta^{13} \mathrm{C}_{\mathrm{VPDB}}$ EDTA used in this study is $-34.6 \%$ and the $\delta^{15} \mathrm{~N}_{\text {air }}$ is $0.9 \%$. The $\mathrm{C} / \mathrm{N}$ value is 5.0 .

${ }^{\mathrm{c}}$ These values were recalculated from individual laboratory data in Scott et al. (2010).

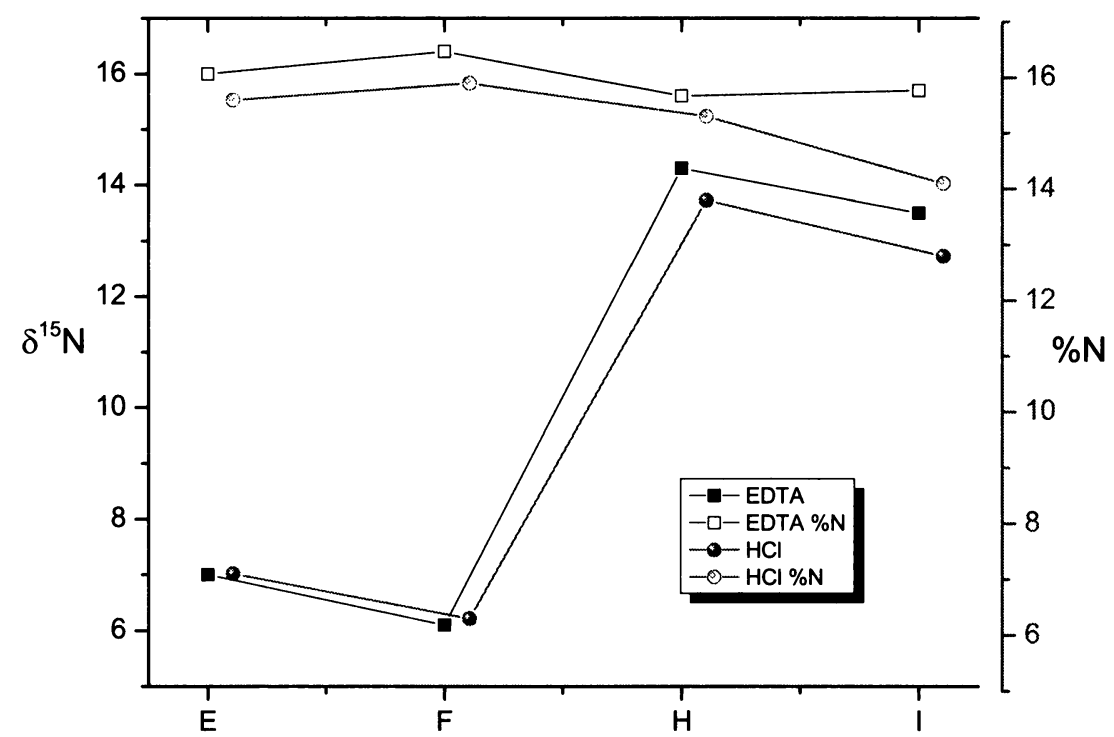

Figure 2 Nitrogen isotopic values $(n=2)$ (bottom 2 lines, left axis) and \% nitrogen (upper 2 lines, right axis) for samples $\mathrm{E}, \mathrm{F}, \mathrm{H}$, and $\mathrm{I}$. The largest loss of nitrogen and the biggest difference is nitrogen isotopic values in seen in sample $\mathrm{I}$.

Natural abundance oxygen isotopes $\left(\delta^{18} \mathrm{O}_{\mathrm{SMOW}}\right)$ are a relatively new type of analysis that is potentially useful in migration and population identity studies (Kirsanow et al. 2008; Tuross et al. 2008; Warinner and Tuross 2009). From a mechanistic standpoint, these isotopic pairs are also uniquely informative about protein chain scission because carboxyl groups of amino acids are exposed during peptide bond breakage and the oxygen atoms are susceptible to exchange (Capelo et al. 2010). The comparative data $\left(\delta^{18} \mathrm{O}_{\text {SMOW }}\right)$ is shown in Figure 3. There was insufficient sample to include VIRI $\mathrm{G}$ in these analyses, and unfortunately the amount of available bone sample did not allow for a preparation of $\mathrm{HCl}$-decalcified, nongelatinized collagen analyses.

The oxygen isotopic values change with gelatinization in samples that are decalcified in either EDTA or $\mathrm{HCl}$ relative to EDTA nongelatinized samples (Figure 3). The differences are most pronounced in the $\mathrm{HCl}$-decalcified/gelatinized samples (relative to nongelatinized, EDTA-decalcified collagens). The difference among the collagen/gelatin preparations within each sample likely results 


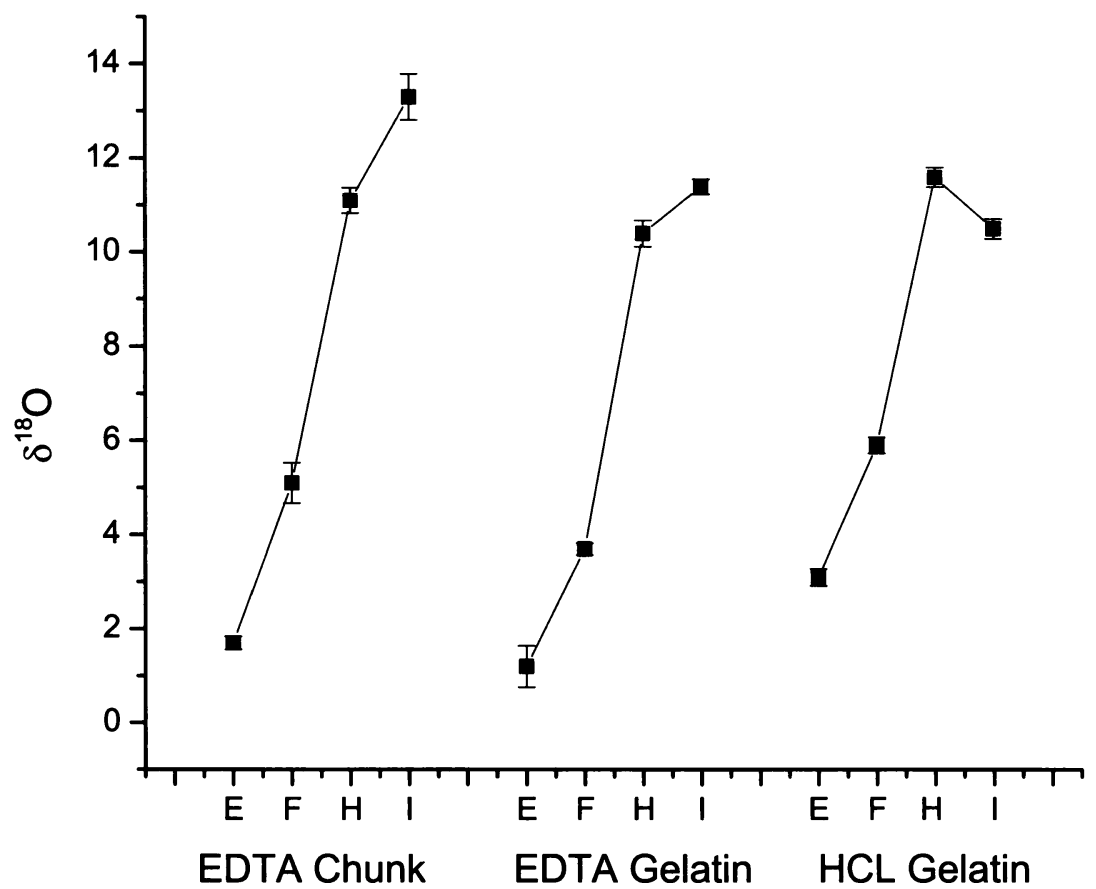

Figure 3 Oxygen isotopic values $(n=3)\left(\delta^{18} \mathrm{O}_{\text {VSMOW }}\right)$ in 4 VIRI bones $(\mathrm{E}, \mathrm{F}, \mathrm{H}$, and I) shown as a function of preparation. The largest variation between preparation types is seen in sample $\mathrm{l}$, but all gelatinized samples are different from the analogous nongelatinized collagen. The overall trend is toward a decreasing range in the samples prepared with $\mathrm{HCl}$ demineralization and subsequent gelatinization that may be due to increasing exchange with water.

from oxygen addition and equilibration that is a necessary consequence of partial hydrolysis and carboxyl exchange at low pH (see Capelo et al. 2010). The measurement of oxygen isotopic values in gelatin could serve as a monitor of peptide bond breakage as part of the preparation. The range of $\delta^{18} \mathrm{O}_{\text {SMOw }}$ values in the VIRI (E, F, H, and I) samples among the 3 preparations was 1.5 to $3.5 \%$, and sample I had the highest variability among the preparations.

\section{DISCUSSION}

The concern that a carbon-containing decalcifying agent might alter ${ }^{14} \mathrm{C}$ dates relative to halide acid (e.g. $\mathrm{HCl}$ ) approaches is not supported by these data. Both radiometric and natural abundance isotopes are within analytical error, and are identical in both $\mathrm{HCl}$ and EDTA preparations in comparison to the VIRI consensus values. This paper does not argue for a substitution of decalcification methods (EDTA for $\mathrm{HCl}$ ) in the preparation of collagen for ${ }^{14} \mathrm{C}$ dating. Using gentle chelating agents such as EDTA for bone decalcification is a much longer process than analogous $\mathrm{HCl}$ demineralization, although much of the time involved does not require close human attention.

This is the first demonstration of the use of EDTA decalcification as part of an international laboratory exercise. Individual samples from both $\mathrm{HCl}$ and EDTA preparations (save 2) overlap $1 \sigma$ of the VIRI consensus values, and none of the individual samples are considered outliers based on $1.5 \mathrm{IQR}$ (Scott et al. 2010), supporting EDTA decalcification as a viable alternative technique in ${ }^{14} \mathrm{C}$ preparations. Reasons for using EDTA decalcification could include limited sample size, the friability remnant collagen and its solubility at low $\mathrm{pH}$, or source material from very young individuals when 
collagen is likely to be more soluble (Flanagan and Nichols 1969). As a practical matter, this laboratory has found that collagen for stable isotopic analyses can be retrieved from many pre-Holocene bone samples only by the use of EDTA decalcification. One further advantage of EDTA decalcification deserves mention. If the extraction is done with the proper controls (see Gilbert et al. 2005), the soluble extract can be saved for future DNA analysis, an option that is not open when $\mathrm{HCl}$ is used to decalcify bones or teeth.

There is a constellation of observations from this study and also the VIRI publication (Scott et al. 2010) that suggest sample I is the most highly degraded sample of the group. Sample I had the largest number of outliers in the VIRI test, the highest standard deviation among the VIRI samples in $\delta^{13} \mathrm{C}$ (when recalculated from individual laboratory data in Scott et al. 2010), the largest amount of nitrogen lost and change in $\delta^{15} \mathrm{~N}$ in the $\mathrm{HCl}$ preparation, and the greatest variation among preparation types in $\delta^{18} \mathrm{O}$.

\section{CONCLUSIONS}

The results confirm the utility of EDTA decalcification of bone for the purpose of ${ }^{14} \mathrm{C}$ dating when compared to both $\mathrm{HCl}$ decalcification performed in the same laboratory and to consensus ages reported from 42 laboratories in the VIRI intercomparison. Natural abundance stable isotope values support the identity of the carbon content in the 2 extraction procedures, but nitrogen and oxygen isotopic analyses of the extracts point to molecular alterations due to analytical procedures.

\section{REFERENCES}

Arslanov KA, Svezhentsev YS. 1993. An improved method for radiocarbon dating fossil bones. Radiocarbon 35(3):387-91.

Beaumont W, Beverly R, Southon J, Taylor RE. 2010. Bone preparation at the KCCAMS laboratory. $\mathrm{Nu}$ clear Instruments and Methods in Physics Research B 268(7-8):906-9.

Bensusan HB, Nielsen SO. 1964. Deuterium exchange of peptide-group hydrogen atoms during the gelatin to collagen-fold transition. Biochemistry 3(9): 1367-72.

Berglund BE, Hakansson S, Lagerlund E. 1976. Radiocarbon-dated mammoth (Mammuthus primigenius Blumenbach) find in South Sweden. Boreas 5:177-91.

Brown TA, Nelson, DE, Vogel JS, Southon JR. 1988. Improved collagen extraction by modified Longin method. Radiocarbon 30(2):171-7.

Capelo JL, Carreira RJ, Fernandes L, Lodeiro C, Santos HM, Simal-Gandara JL. 2010. Latest developments in sample treatment for ${ }^{18} \mathrm{O}$-isotopic labeling for proteomics mass spectrometry-based approaches: a critical review. Talanta 80(4):1476-86.

Eastoe JE. 1955. The amino acid composition of mammalian collagen and gelatin. Journal of Biological Chemistry 61(4):589-600.

El-Daoushy MFAF, Olsson IU, Oro FH. 1978. The EDTA and $\mathrm{HCl}$ methods of pre-treating bones. Geologiska Föreningens $i$ Stockholm Förhandlingar 100: 213-9.

Flanagan B, Nichols Jr G. 1969. Bone matrix turnover and balance in vitro: II. The effects of ageing. Journal of Clinical Investigation 48(4):607-12.
Frank JD, Balena R, Masarachia P, Seedor G, Cartwright ME. 1993. The effect of three different demineralization agents on osteopontin localization in adult rat bone using immunohistochemistry. Histochemistry and Cell Biology 99(4):295-301.

Gilbert MTP, Bandelt H-J, Hofreiter M, Barnes I. 2005. Assessing ancient DNA studies. Trends in Ecology and Evolution 20(10):541-4.

Gurfinkel DM. 1987. Comparative study of the radiocarbon dating of different bone collagen preparations. Radiocarbon 29(1):45-52.

Haynes CV. 1967. Bone organic matter and radiocarbon dating. In: Radiocarbon Dating and Methods of LowLevel Counting. Vienna: International Atomic Energy Agency. p 163-8.

Hedges REM, van Klinken GJ. 1992. A review of current approaches in the pretreatment of bone for radiocarbon dating by AMS. Radiocarbon 34(3):279-91.

Higham TFG, Jacobi RM, Bronk Ramsey C. 2006. AMS radiocarbon dating of ancient bone using ultrafiltration. Radiocarbon 48(2): 179-95.

Jackson DS, Bentley JP. 1960. On the significance of the extractable collagens. Journal of Cell Biology 7(1): $37-42$.

Kirsanow K, Makarewicz C, Tuross N. 2008. Stable oxygen $\left(\delta^{18} \mathrm{O}\right)$ and hydrogen $(\delta D)$ isotopes in ovicaprid dentinal collagen record seasonal variation. Journal of Archaeological Science 35(12):3159-67.

Liu H, Fang HHP. 2002. Extraction of extracellular polymeric substances (EPS) of sludges. Journal of Biotechnology 95:249-56. 
Longin R. 1971. New method of collagen extraction for radiocarbon dating. Nature 230(5291):241-2.

Olsson I. 2000. Further tests of the EDTA treatment of bones. Radiocarbon 42(1):49-52.

Olsson IU, El-Daoushy M, Farid AF, Abd-El-Mageed AI, Klasson M. 1974. A comparison of different methods for pretreatment of bones I. Geologiska Föreningens $i$ Stockholm Förhandlingar 96:171-81.

Pestle WJ. 2010. Chemical, elemental, and isotopic effects of acid concentration and treatment duration on ancient bone collagen: an exploratory study. Journal of Archaeological Science 37(12):3124-8.

Piszkiewicz D, Landon M, Smith EL. 1970. Anomalous cleavage of aspartyl-proline peptide bonds during amino acid sequence determinations. Biochemical and Biophysical Research Communications 40(5):1173-8.

Salamon M, Tuross N, Arensburg B, Weiner S. 2005. Relatively well preserved DNA is present in the crystal aggregates of fossil bones. Proceedings of the $\mathrm{Na}$ tional Academy of Sciences USA 102(39):13,783-8.

Scott EM, Cook GT, Naysmith P. 2010. A report on Phase 2 of the Fifth International Radiocarbon Intercomparison (VIRI). Radiocarbon 52(2-3):846-58.

Sharp ZD, Atudorei V, Durakiewicz T. 2001. A rapid method for determination of hydrogen and oxygen isotope ratios from water and hydrous minerals. Chemical Geology 178(1-4):197-210.
Silva T, Kirkpatrick A, Brodsky B, Ramshaw JAM. 2005. Effect of deamidation on stability for the collagen to gelatin transition. Journal of Agricultural and Food Chemistry 53(20):7802-6.

Tuross N, Fogel ML, Hare PE. 1988. Variability in the preservation of the isotopic composition of collagen from fossil bone. Geochimica et Cosmochimica Acta 54(4):929-35.

Tuross N, Warinner C, Kirsanow K, Kester C. 2008. Organic oxygen and hydrogen isotopes in a porcine controlled dietary study. Rapid Communications in Mass Spectrometry 22(11):1741-5.

Veis A. 1964. The Macromolecular Chemistry of Gelatin. New York: Academic Press.

Veis A, Anesey J. 1965. Modes of intermolecular crosslinking in mature insoluble collagen. The Journal of Biological Chemistry 240(10):3899-908.

Warinner C, Tuross N. 2009. Alkaline cooking and stable isotope tissue-diet spacing in swine: archaeological implications. Journal of Archaeological Science 36(8):1690-7.

Zhang Z, Guoying L, Shi B. 2006. Physiochemical properties of collagen, gelatin and collagen hydrolysate derived from bovine limes split wasters. Journal of the Society of Leather Technologists and Chemists 90:238. 